This item is the archived peer-reviewed author-version of:

Alexander Sutherland : a forgotten pioneer of health economics in Australia?

\title{
Reference:
}

Clarke Philip, Erreygers Guido.- Alexander Sutherland : a forgotten pioneer of health economics in Australia?

The Australian economic review - ISSN 0004-9018 - 49:2(2016), p. 169-173

Full text (Publisher's DOI): https://doi.org/10.1111/1467-8462.12157

To cite this reference: http://hdl.handle.net/10067/1337660151162165141 


\section{Alexander Sutherland: A Forgotten Pioneer of Health Economics in Australia?}

Philip Clarke and Guido Erreygers*

* Clarke: Centre for Health Policy, The University of Melbourne, Victoria 3010 Australia; Erreygers: Centre for Health Policy, The University of Melbourne, Victoria 3010 Australia, and Department of Economics, University of Antwerp, Antwerpen 2000 Belgium. Corresponding author: Clarke, email <philip.clarke@unimelb.edu.au>. We thank John González, Joseph P. Newhouse, Lies Vidts and the reviewers of this Journal for their suggestions and comments. All errors are our responsibility.

\section{Abstract}

Here we highlight a neglected contribution of Alexander Sutherland (1852-1902) to Australian health economics. Sutherland read a paper on health insurance at the Melbourne Social Science Congress that was organised in the context of the International Exhibition of 1880-1881. He proposed combining life and health insurance into a single product and to require those who are insured to obtain regular medical check-ups. The aim was to provide the insurer with information on the behaviours of the insured and to promote healthy lifestyles. These proposals were not well received at the time and have been largely forgotten, but may be relevant today.

\section{The Melbourne Social Science Congress}

In June 1879, when the preparations for the Melbourne International Exhibition began to gather steam, Thomas Loader, one of its commissioners, launched the initiative to organise 
a Social Science Congress at the same time. His inspiration seems to have come from the success of similar meetings held during the Exposition Universelle in Paris in $1878^{1}$ and from the conferences organised in Great Britain by the National Association for the Promotion of Social Science. ${ }^{2}$ A large number of 'scientific, literary, artistic, philanthropic, commercial, and other associations in Melbourne and suburbs' were invited to appoint delegates to prepare the Congress. ${ }^{3}$ The delegates met in October $1879,{ }^{4}$ and soon thereafter, a council was elected. ${ }^{5}$ By the beginning of 1880 , it was decided that the Congress would consist of six departments: Jurisprudence; Education; Health; Agriculture, horticulture and pastoral pursuits; Economy, trade and manufactures; and Literature, science, music and the fine arts. $^{6}$

The Health section was organised primarily by medical doctors and headed by William McCrea (1814-1899), Chairman of Victoria's Central Board of Health from 1853 to 1879. The intended focus, as outlined in the call for papers, was primarily on public health issues including the construction and ventilation of houses and hospitals, drainage, water and sewerage, as well as the registration and control of contagious diseases. ${ }^{7}$ The organisers did not exclude papers written by 'non-medical persons', but these should be intended for an audience interested in 'sanitary questions'. ${ }^{8}$

On 11 October 1880, just a few days after the opening of the Melbourne International Exhibition, the Congress held its first meeting with an inaugural address by the astronomer, Robert Lewis Ellery (1827-1908), the President of the Melbourne Social Science Congress. ${ }^{9}$ The Congress was covered extensively in the local newspapers; The Australasian, for instance, argued that scientific associations of this kind should act as 'sort of middlemen between scientists and the public'.$^{10}$ International professional journals, such as the British 
Medical Journal, provided several reports from a Melbourne-based correspondent. ${ }^{11}$ In the following weeks, one after the other, each of the six departments organised numerous sessions in which a broad variety of papers and contributions was presented and discussed.

\section{Health Insurance}

On 20 October 1880, the Health department of the Congress held two sessions, one in the afternoon and one in the evening, with two papers being presented and discussed in each session. During the afternoon session, attended by about 40 people, the architect, Lloyd Tayler (1830-1900), read a paper on 'Dwellings for the industrial classes', in which he suggested the destruction of unsuitable housing and 'the erection of large blocks of buildings on ground to be purchased or leased for the purpose'. ${ }^{12}$ His proposal was apparently well received and the discussion focused on the practical aspects of the scheme. The mood shifted when A. Sutherland M.A. read the next paper, on 'Health insurance', in which he advocated the introduction of a combined health and life insurance system. The proposal did not go down very well; one newspaper reported that a 'brief discussion followed, in which the suggestions contained in the paper were generally condemned as impracticable', ${ }^{13}$ while another politely summarised it as 'a somewhat Utopian paper'. ${ }^{14}$

Unfortunately, Sutherland's paper was never published and has been forgotten completely. Even though Ellery, speaking in his capacity as President of the Royal Society of Victoria, had claimed in September 1881 that: 'Many of the papers contributed are now being printed, and will, I believe, soon be issued as the "Proceedings of the Melbourne Social Science 
Congress"', 15 the publication never saw the light of day. It is unclear to what extent the criticism of the Social Science Congress played a role in this. While some lamented the lack of interest in the sessions, ${ }^{16}$ others scorned it as 'the most absurd, grotesque, and useless excresence in connection with our Great Exhibition, not even excluding the fountain' ${ }^{17}$

Two newspapers published abstracts of Sutherland's paper. ${ }^{18} \mathrm{~A}$ slightly longer abstract was published in a medical journal. ${ }^{19}$ It seems useful to quote in full the longest version:

The author, assuming that many diseases are preventible, and that medical advice is sought only when disease has actually commenced, proposes the formation of insurance companies whose object should be to secure efficient medical attendance during health, periodical visits being paid by the medical officer by way of inspection, so as to make certain that the insurer was living under conditions favourable to the preservation of health. He thinks that the success of fire, life, and marine insurance offers encouragement for similar associations in respect of health. He proposes that the health insurance system should be in combination with life insurance, so that the directors of these latter companies might be able to declare the vitiation of a policy when it was known that the holder of it was disregarding the means of preserving his health, and so of shortening his life. The author admits the possibility of such medical inspection being distasteful to many persons, whom it would subject to domiciliary visits in the nature of espionage, but he claims that the benefits arising from such a system would more than counterbalance the irksomeness of the inspector's visits. He claims that the method he proposes would help to diffuse a wider and better knowledge of the laws relating to health, and that many persons who now ignorantly practice habits which lead to disease, would, by means of such medical direction as is proposed, give up bad habits, and so secure for themselves better health and longer lives. In this way the loss and misery arising from prolonged sickness would be minimised, and the average mortality, especially among children, greatly lessened. ${ }^{20}$ 
From the newspaper reports, it is impossible to deduce which aspects of the proposal the audience found hard to swallow. More can be gleaned from the coverage of the paper by The Australasian Insurance and Banking Record, undoubtedly reflecting the views of the insurance industry. The lengthy article in this review included the same Abstract as the one published by The Age, but consisted mainly of a rather harsh criticism of Sutherland's proposals, even though the Editors admitted they were not present at the reading of the paper. ${ }^{21}$ They characterised Sutherland's health insurance scheme as one of the most 'quixotic' and 'utopian' ever devised and ridiculed and dismissed what they perceived as 'feel-your-pulse policies'. The Journal's criticism was largely based on scepticism about the usefulness of doctors being engaged in preventative medical check-ups: 'It seems rather a paradox to have medical attendance during health'. The Editors also objected to the continuation of insurance policies being dependent on the health behaviours of the insured:

\footnotetext{
We assume that the inspecting medical officer would be empowered to dictate as to what articles of diet should be used, and in what quantities, and how many or how few glasses of wine were to be drunk - a limit especially being set on the allowance for festive gatherings. Alas! for the feast of reason and the flow of soul, when the thought would continually be surging through the brain, "Another glass, and my policy will be vitiated!" The soundest policy to be followed in such a case would be to eschew all convivial entertainments, where any beverages stronger than water appeared on the festive board. ${ }^{22}$
}

In addition, they argued that, from 'an insurance point of view', health inspection policies would be so unpopular as to bankrupt any firm offering them. They concluded that 'the utter implacability of the whole scheme should be its own condemnation'. 


\section{Today's Relevance}

What are we to think about Sutherland's proposals? Given that they were formulated before the rise of both national health insurance schemes and the deepening of private health insurance markets in many countries, including Australia, are they still relevant today?

Health and life insurance products have tended to evolve quite separately. There have been proposals for combining income annuities with long-term-care disability coverage on the basis that insurers can reduce adverse selection by pooling two very different risk groups; that is, those experiencing long lives and those experiencing short lives with disabilities (Murtaugh, Spillman and Warshawsky 2001). However, given the positive correlation between mortality and health expenditure, ${ }^{23}$ the potential benefits of risk pooling of health and life insurance are not that clear.

The idea of linking health insurance to the adoption and encouragement of healthy lifestyles was, as far as we can see, an entirely original approach. Nothing like that seems to have emerged when sickness funds were developed in the 19 th century. ${ }^{24}$ Sutherland's proposals for health or life insurance policies to contain a requirement for the insured to undergo regular check-ups have not been taken up widely by insurers within either of these industries. The monitoring of the behaviour of the insured is, however, becoming a feature of car insurance, where some Pay-As-You-Drive policies reward consumers with lower premiums if they keep to the speed limit (see, for instance, Bolderdijk et al. 2011). The role 
of prevention in the design of optimal health insurance contracts has only been explored relatively recently in the health economics literature. ${ }^{25}$

\section{Alexander Sutherland}

Sutherland's other work provides no clue about the details of his health insurance scheme. Maybe, the hostile reception of his ideas at the Melbourne Social Science Congress and from the insurance industry persuaded him to abandon the project. The least we can say is that he had many other things on his mind. Alexander Sutherland, born in Scotland in 1852, was a polymath. ${ }^{26}$ He was schoolmaster at Carlton College, lecturer, author of textbooks, journalist, poet, novelist, scientist and much more. ${ }^{27}$ In 1902, the year in which he died, he was appointed Registrar of the University of Melbourne. Some of his contributions to economics-but not the 1880 health insurance paper-are mentioned in the two reference works on the history of economic thought in Australia (Goodwin 1966; Groenewegen and McFarlane 1990).

We can only speculate whether Australian health economics was nipped in the bud in 1880 . It is intriguing to know that, in July 1879, Alexander Sutherland presented a paper on the application of mathematics to political economy during the first meeting of Section A, 'Physical, Astronomical, and Mechanical Science, Including Engineering', of the Royal Society

of Victoria. ${ }^{28}$ No further information on this paper can be found in the publications and archives of the Royal Society of Victoria. The following two reports suggest it may have been an exciting meeting: 
Mr. Sutherland read a short and interesting paper on the application of mathematics to political economy. He pointed out that considerable antagonism had been expressed against the introduction of mathematics in political researches by philosophers; but now the necessity of keeping abreast of modern thought was recognised, and original research with regard to electricity and magnetism was almost confined to the mathematician. The paper was discussed at considerable length, and the meeting adjourned. ${ }^{29}$

Mr. Sutherland read a paper on the application of mathematics to political economy, in which he submitted that the time was no doubt coming when political economy would have made all the advance it could with its present means, and would call in the powerful aid of mathematics, to which the other sciences had been obliged to resort. Political economy was, he considered, quite as susceptible of assistance from mathematics as any of the physical sciences, because it was a science which had throughout to deal with magnitudes capable of measurement and numerical representation. ${ }^{30}$

Sadly enough, we have been unable to find a copy of the paper. It would have been interesting to know to what extent Sutherland was aware of the work of the protagonists of the neo-classical revolution, such as William Stanley Jevons and Léon Walras, and to compare his ideas to theirs. What we can say, however, is that he had a keen interest in political economy and was not afraid to launch bold new ideas. 


\section{References}

Bolderdijk, J. W., Knockaert, J., Stega, E. M. and Verhoef, E. T. 2011, 'Effects of Pay-As-You-Drive vehicle insurance on young drivers' speed choice: Results of a Dutch field experiment', Accident Analysis and Prevention, vol. 43, pp. 1,181-6.

Ellery, R. 1882, 'Anniversary address of the president', Transactions and Proceedings of the Royal Society of Victoria, vol. 18, pp. xi-xxv.

Ellis, R. P. and Manning, W. G. 2007, 'Optimal health insurance for prevention and treatment', Journal of Health Economics, vol. 26, pp. 1,128-50.

González, J. 2010, 'Alexander Sutherland (1852-1902): Forgotten Australian intellectual', Australian Studies, vol. 2, ser. 2, viewed XXX, <http://www.nla.gov.au/openpublish/index.php/australianstudies/article/view/1749/2148>.

Goodwin, C. D. W. 1966, Economic Inquiry in Australia, Duke University Press, Durham, North Carolina.

Groenewegen, P. and McFarlane, B. 1990, A History of Australian Economic Thought, Routledge, London.

Hennock, E. P. 2007, The Origin of the Welfare State in England and Germany, 1850-1914, Cambridge University Press, Cambridge.

Murtaugh, C. M., Spillman, B. C. and Warshawsky, M. J. 2001, 'In sickness and in health: An annuity approach to financing long-term care and retirement income', Journal of Risk and Insurance, vol. 68 , pp. $225-54$.

Seshamani, M. and Gray, A. M. 2004, 'A longitudinal study of the effects of age and time to death on hospital costs', Journal of Health Economics, vol. 23, pp. 217-35.

Turner, H. G. 1908, Alexander Sutherland, M.A.: His Life and Work, T. C. Lothian, Melbourne. 


\section{Endnotes}

1. The Argus, 16 June 1879, p. 5.

2. The Australasian, 21 June 1879, p. 19.

3. The Australasian, 21 June 1879, p. 19.

4. The Argus, 10 October 1879, p. 3.

5. The Australasian, 1 November 1879, p. 20.

6. The Age, 22 January 1880 , p. 5.

7. Australian Medical Journal, 15 March 1880, New Series, vol. 2, pp. 129-31.

8. Australian Medical Journal, 15 March 1880, New Series, vol. 2, p. 131.

9. The Argus, 12 October 1880, p. 6.

10. The Australasian, 16 October 1880, p. 40.

11. British Medical Journal, 31 January 1880, p. 184; 8 May 1880, p. 716; 26 February 1881, pp. 319-20.

12. The Argus, 21 October 1880, p. 10.

13. The Argus, 21 October 1880, p. 10.

14. The Australasian, 23 October 1880, p. 3.

15. Ellery (1882, p. xxiv). Already in the beginning of 1881, the correspondent of the British Medical Journal had announced that the papers of the Health section 'are to appear in extenso in a volume of proceedings' (26 February 1881, p. 130).

16. The Sydney Morning Herald, 28 October 1880, p. 7.

17. Melbourne Punch, 18 November 1880, p. 6.

18. The Argus, 21 October 1880, p. 10; The Age, 22 October 1880, p. 3. The version of The Argus is slightly longer than the one of The Age. 
19. Australian Medical Journal, November 1880, New Series, vol. 2, p. 485.

20. Australian Medical Journal, November 1880, New Series, vol. 2, p. 485 . The Abstract is preceded by the note: 'The following abstracts of the papers read before the Section have been kindly furnished by the Hon. Sec., Dr. J. E. Neild'. The last two sentences are absent in the versions published by The Argus and The Age, but it seems legitimate to suppose that all of these accounts are based on the same source.

21. 'Health insurance: Or "Feel-your-pulse policies"', The Australasian Insurance and Banking Record, 10 November 1880, vol. 4, pp. 382-3.

22. 'Health insurance: Or "Feel-your-pulse policies"', The Australasian Insurance and Banking Record, 10 November 1880, vol. 4, p. 382.

23. There is now a large literature quantifying the association between time to death and health care expenditure; see, for example, Seshamani and Gray (2004).

24. See, for instance, the comparative study of the origins of the welfare state in England and Germany by Hennock (2007).

25. For example, Ellis and Manning (2007) have developed a theoretical model to examine optimal co-insurance rates for health care prevention and treatment.

26. More biographical details can be found in Turner (1908) and González (2010).

27. For instance, he read another paper at the Melbourne Social Science Congress in which he advocated that children in schools should not have their time wasted in being taught Latin and Greek, unless they were intended for the learned professions' (Leader, 16 October 1880 , p. 23). 
28. 'Proceedings of Section A. Physical, astronomical, and mechanical science, including engineering', Transactions and Proceedings of the Royal Society of Victoria, 1880, vol. 16, p. 188.

29. The Age, 3 July 1879, p. 3; exactly the same text was published in Leader, 5 July 1879, p. 20.

30. The Argus, 3 July 1879, p. 5; exactly the same text was published in The Australasian, 5 July 1879, p. 20 . The publication of these reports suggests an account of the meeting may have been circulated to the press. 